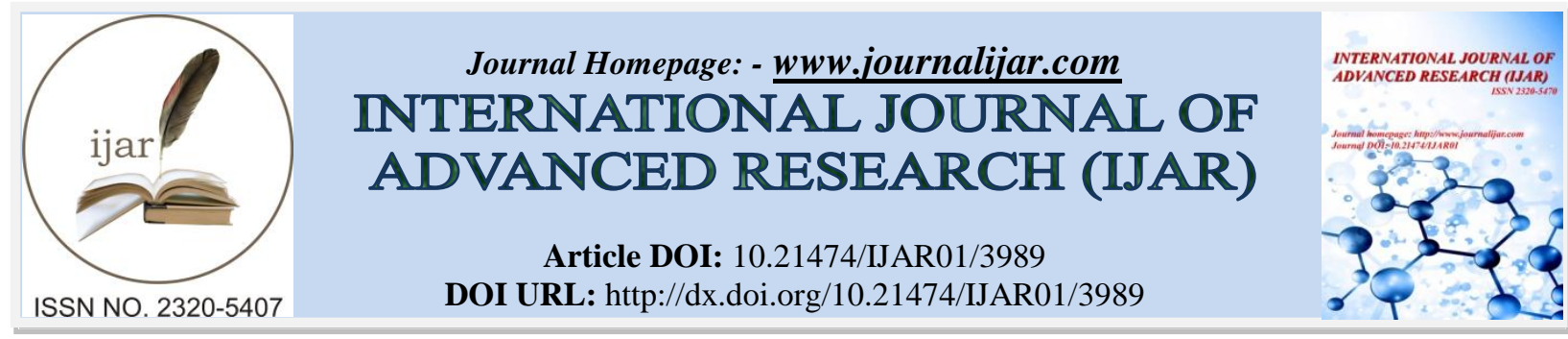

RESEARCH ARTICLE

\title{
PHENYTOIN AND SODIUM VALPROATE INTOXICATION AND MANAGEMENT, A CASE REPORT
}

\author{
Dr. Surya Prakash Yarramalle ${ }^{1}$, Dr. Kartik Munta ${ }^{1}$, Dr. S. Manimala Rao ${ }^{1}$, Dr. Hemanth. $C^{2}$, Dr. \\ Dhanalakshmi ${ }^{2}$ and Dr. Sohal Parate ${ }^{1}$. \\ 1. Department Of Critical Care Medicine, Yashoda Multi-Speciality Hospital, Somajiguda, Hyderabad, India. \\ 2. Department Of General Medicine, Yashoda Multi-Speciality Hospital, Somajiguda, Hyderabad, India \\ 3. Department Of Nephrology, Yashoda Multi-Speciality Hospital, Somajiguda, Hyderabad, India.
}

\section{Manuscript Info}

Received: 22 February 2017

Published: April 2017

Key words:-

Phenytoin Toxicity, Sodium Valproate

Toxicity, Plasma Pheresis.

\section{Manuscript History}

Final Accepted: 18 March 2017

\begin{abstract}
Phenytoin Toxicity Is Challenging Due To Its Pharmacokinetic Properties And Narrow Therapeutic Index. Serum Values In Valproate Toxicity Do Not Correlate With Its Side Effects. In This Case Report, Patient Consumed 100 Tablets Of Phenytoin And 15 Tablets Of Sodium Valproate Causing Her Serum Levels Of Phenytoin And Valproate Rise To 100mcg/Ml And 1.4mcg/Ml Respectively. Her Conditioned Worsened And Suffered Cardiac Arrest On $9^{\text {th }}$ Day Of Admission During Supportive Therapy. Plasma Pheresis Was Done As Rescue Measure Which Decreased Phenytoin Levels. Her Neurological Condition Improved And Was Discharged After 40 Days Of Hospital Stay.
\end{abstract}

Copy Right, IJAR, 2017,. All rights reserved.

\section{Introduction:-}

Phenytoin Sodium And Sodium Valproate Are Few Of The Commonly Used Antiepileptics. Overdosage Of These Drugs Occurs Due To Suicidal Intent Or Inadequate Monitoring Of The Therapy. Phenytoin At Lower Doses Follows First Order Kinetics And At Higher Doses Follows Zero Order Kinetics. Henceforth Management Of Its Toxicity Is Challenging As Its Removal From The Body Takes Longer Duration. ${ }^{[1]}$ Few Side Effects Of Sodium Valproate Toxicity Includes Hyperammonemia, Raised Hepatic Transaminases And Pancreatitis. ${ }^{[2]}$ We Report A Case Of Suicidal Consumption Of 100 Phenytoin Tablets Each Of 100mg And 15 Tablets Of $200 \mathrm{Mg}$ Sodium Valproate.

\section{Case Report:-}

A 28 Year Old Female Presented 10 Hours After Consumption Of 100 Tablets Of 100 Mg Phenytoin And 15 Tablets Of $200 \mathrm{Mg}$ Sodium Valproate. She Was Treated At Local Hospital 2 Hours After Consumption With Gastric Lavage And Shifted To Our Hospital. At Presentation, She Was Conscious, Oriented With Nystagmus, Diplopia And Slurring Of Speech. Electrocardiogram Showed Prolonged Qtc Interval (580msec). Serum Phenytoin, Ammonia And Sodium Valproate Levels Were $>100 \mathrm{mcg} / \mathrm{Ml}, 40 \mathrm{mmol} / \mathrm{L}$ And1.4mcg/Ml Respectively With Sgot Of 57iu/L And Sgpt Of76iu/L. She Was Shifted To Icu, Where She Became Drowsy, Irritable After 6 Hours. She Was Treated Conservatively With Lipid Emulsion For Prolonged Qtc Interval. She Was Intubated And Ventilated In View Of Low Gcs (Glasgow Coma Scale). Her Serum Ammonia Increased To $56 \mathrm{mmol} / \mathrm{L}$ Where As Serum Phenytoin Level Came Down To 33.70 Mcg/Ml. Percutaneous Tracheostomy Was Performed On Day 8 In View Of Neurological Status And Prolonged Ventilator Support. Tracheal Secretions Showed Acinetobacter And Was Treated With Appropriate Antibiotics. Mri Of Brain Showed Normal Study With Global Cerebral Dysfunction On 
EEG. Serum Phenytoin Levels On $9^{\text {th }}$ Day Of Admission Increased To $50.90 \mathrm{Mcg} / \mathrm{Ml}$ And Patient Remained Irritable And Not Obeying Commands. Patient Suffered A Cardiac Arrest, And Hypothermia Was Instituted On Day 9. Plasmapheresis Was Planned In An Attempt To Decrease Phenytoin Levels Due To Progressive Worsening. Her Serum Phenytoin Levels Decreased To27.3mcg/Ml Post Plasma Pheresis. A Day After Cardiac Arrest Patient Showed Spontaneous Eye Opening With Persistent Nystagmus. Serum Phenytoin Levels Were Monitored Regularly And Were 8.2mcg/Ml On Day 21. Serum Ammonia Level Also Decreases From 125mmol/L To 64mmol/L. In View Of Repeated Episodes Of Abdominal Distention Sodium Valproate Induced Acute Pancreatitis Was Suspected. Serum Amylase And Lipase Levels Were Elevated 257 U/L And 788u/L Respectively. Sigmoid Decompression Was Done On $16^{\text {th }}$ Day Of Admission For Recurring Episodes Of Abdominal Distention. As Her Irritability Decreased, Sensorium Improved, Ventilator Support Weaned And Was Decannulated On 28thday Of Admission. Patient Was Shifted Out Of Icu And Was Later Discharged After 40 Days Of Hospital Stay.

\section{Discussion:-}

After Consumption, Phenytoin Precipitates In Acid Environment Of Stomach And This Plays An Important Role In Over Dosage. It Is Metabolized By Hepatic Microsomal Enzymes And Is Highly Protein Bound. Only Free Unbound Phenytoin Is Biologically Active. Peak Blood Levels Are Seen 3-12 Hours After Ingestion. Phenytoin Levels In Cns Are Higher Than Plasma Levels Henceforth Serum Phenytoin Levels May Underestimate Cns Concentration Levels. ${ }^{[3]}$ This Might Be The Reason In Our Patient Too. Cns Toxicity May Lead To Damage To Cerebellum Manifesting As Cerebellar Atrophy. Ataxic Gait, Nystagmus And Mental Status Changes Are Early Signs Of Toxicity Which Were Noted In Our Patient.[Table 1]

Table 1:- Serum Phenytoin Level And Toxicity.

\begin{tabular}{|c|c|}
\hline Serum Phenytoin Level & Signs And Symptoms \\
\hline $10-20 \mathrm{Mcg} / \mathrm{Ml}$ & Therapeutic Range \\
\hline $20-30 \mathrm{Mcg} / \mathrm{Ml}$ & Nystagmus \\
\hline $30-40 \mathrm{Mcg} / \mathrm{Ml}$ & Ataxia, Slurred Speech, Nausea And Vomiting \\
\hline $40-50 \mathrm{Mcg} / \mathrm{Ml}$ & Lethargy And Confusion \\
\hline Higher Than $50 \mathrm{Mcg} / \mathrm{Ml}$ & Coma And Seizures \\
\hline
\end{tabular}

Management Includes Prolonged Supportive Care And Treatment Of Secondary Infections. Case Reports Regarding Use Of Multiple Doses Of Activated Charcoal Exists But Nausea And Vomting May Occur, Leading To Aspiration Pneumonia. ${ }^{[4]}$ Usage Of Charcoal Hemoperfusion Decreased Serum Phenytoin Levels In Paediatric Case Reports. ${ }^{[5]}$ In Presence Of Activated Charcoal, Hemoperfusion Causes Bound Phenytoin To Dissociate From Albumin And Gets Adsorbed To It. ${ }^{[6]}$ Molecular Adsorbent Recirculating System Has Been Shown To Cause Reduction Of Phenytoin Levels Across Charcoal Column Indicating Main Site Of Removal Of Drug Bound To Albumin. ${ }^{[7]}$ But Usage Of Mars Has Been Limited By Its Availability And High Costs. Use Of Plasmapheresis Resulted In Drop Of Protein Bound Drug In Some Studies. ${ }^{[8]}$ Our Patients Gcs Improved And Showed A Significant Drop In Phenytoin Levels From 50.90 To 27.30 Mcg/Ml Post Plasmapheresis. Phenytoin Induced Inhibition Of Cardiac Sodium Channels Especially At Phase 0 Causing Inward Intracellular Sodium Currents Leading To Slowing Of Conduction And Widening Of The Qrs Complex Has Been Attributed As A Cause For Bradyarrhythmia's. ${ }^{[9]}$ In Our Case This Could Have Been The Cause Of Bradycardia And Cardiac Arrest As The Levels Of Phenytoin Have Also Been High (50.90) At The Same Time. Intravenous Lipid Emulsion Therapy Can Be Considered For Toxicity Of Lipophilic Drugs Causing Prolonged Qtc Interval. ${ }^{[10]}$ Drugs Like Phentoin And Valproic Acid Are Highly Lipid Soluble. Henceforth Lipid Emulsion Was Used In Our Case.

Valproic Acid Is Rapidly Absorbed After Consumption And Is 90\% Protein Bound. Peak Serum Concentrations Can Be Varying From 1 To 20 Hours After Consumption Depending Upon The Type Of Preparations.There Are Reports That Over Dosing Of Enteric Coated Valproate Sodium May Result In Delayed Toxicity. ${ }^{[11]}$ Two Mechanisms Were Proposed For Hyperammonemia, A Complication Of Valproate Overdose. The First Mechanism Commonly Seen In Young Individuals With Neurological Illness Is Due To An Idiosyncratic Reaction To Sodium Valproate Causing Liver Injury. ${ }^{[12]}$ Second Mechanism Is By Inhibiting Enzymes Of The Urea Cycle In Patients With Normal Liver Functions And Without Any Liver Injury. ${ }^{[13]}$ Patient's Drowsiness Is Related To High Serum Ammonia Levels. Studies Have Shown That Blood Ammonia Levels Do Not Correlate With Blood Levels Of Valproic Acid As Seen In Our Case ${ }^{[14]}$ Acute Pancreatitis Had Also Been Reported As A Very Rare Complication Of Valproic Acid Overdose With An Incidence Of 1:40,000. ${ }^{[15]}$ The Exact Mechanism Of Valproate Induced Pancreatitis Is Unknown. 


\section{Conclusion:-}

Antiepileptic Drugs Intoxication Can Be Suicidal Or Accidental. Among Them, Management Of Penytoin Intoxication Is Challenging. Only Supportive Care Plays An Important Role, Plasmapheresis Can Be Helpful In Scenarios Where Improvement Is Not Evident. In Valproic Acid Overdose, Though The Initial Serum Values Of Drug Is Normal, Complications Like Hyperammonemia And Pancreatitis Should Always Be Suspected.

\section{References:-}

1. Eadie Mj, Tyrer Jh. Anticonvulsant Therapy—Pharmacological Basis And Practice. 3rd Edn. New York: Churchill Livingstone, 1989:51-135.

2. Frye Ma, Post Rm. Valproate. In: Sadock Bj, Sadock Va Editors. Comprehensive Textbook Of Psychiatry. 8th Edition. Philadelphia: Lippincott Williams And Wilkins; 2005; P. 2756-66.

3. Tunca Z, Ozerdem A. Mood Satbilzers . Yüksel N Ed. Essential Psychopharmacology. Ankara: Tu.The Publications Of The Psychiatric Association Of Turkey; 2010; P. 719-752.

4. Chan Bs, Sellors K, Chiew Al, Buckley Na. Use Of Multi-Dose Activated Charcoal In Phenytoin Toxicity Secondary To Genetic Polymorphism. Clin Toxicol(Phila). 2015 Feb. 53 (2):131-3.

5. Kumar Pp, Lingappa L, Shah Ma, Shaikh Fa. Charcoal Hemoperfusion For Phenytoin Intoxication. Indian Pediatr. 2012;49(2):152-153.

6. Lowry Ja, Vandover Jc, Degreeff J, Scalzo Aj. Unusual Presentation Of Iatrogenic Phenytoin Toxicity In A Newborn. Int J Med Toxicol. 2004;4:26-9.

7. Sen S, Ratnaraj N, Davies Na, Mookerjee Rp, Cooper Ce, Patsalos Pn, Et Al. Treatment Of Phenytoin Toxicity By The Molecular Adsorbents Recirculating System (Mars). Epilepsia. 2003;44:265-7.

8. Guido F, William Fc, Shih Hsh. Tandem Hemodialysis And Plasma Exchange. Pediatrnephrol. 2014;29(11):77-82.

9. Wit Al, Rosen Mr, Hoffman Bf. Electrophysiology And Pharmacology Of Cardiac Arrhythmias: Cardiac Effects Of Diphenylhydantoin. Am Heart J 1975;90:397-404.

10. Presley Jd, Chyka Pa. Intravenous Lipid Emulsion To Reverse Acute Drug Toxicity In Pediatric Patients. Ann Pharmacother. 2013;47:735-43.

11. Pons S, Gonzva J, Prunet B, Gaillard T, Brisou P, Vest P. Acute Overdose Of Enteric Coated Valproic Acid And Olanzapine: Unusual Presentation And Delayed Toxicity. Clin Toxicol (Phila). 2012 Apr. 50(4):268.

12. Raskind J, El-Chaar G. The Role Of Carnitine Supplementation During Valproic Acid Therapy. The Annals Of Pharmacotherapy 2000;34:630-638.

13. Coude Fx, Rabier D,Cathelineau L,Et Al.Letter To The Editer: Amechanism For Valproate Induced Hyperammonaemia. Paediatric Research 1981; 15:974- 975.

14. Zaret Bs,Beckner Rr,Marini Am,Wagle W,Passaralli C. Sodium Valproate- Induced Hyperammonaemia Without Clinical Hepatic Dysfunction. Neurology 1982; 32(2):206-208.

15. Gerstner T, Büsing D, Bell N Et Al. Valproic Acid-Induced Pancreatitis:16 New Cases And A Review Of The Literature. J Gastroenterol. 2007;42(1):39-48. 